\title{
Immobilization of Zymomonas mobilis In situ in Flexible Polyurethane and Potential for Bioconversion in Sodium Maltobionate
}

\author{
Roberta Cristina de Souza ${ }^{1}\left(\mathbb{D}\right.$, Leonardo Meirelles da Silva ${ }^{1}{ }^{(\mathbb{D})}$, Sabrina Carra ${ }^{2}{ }^{\mathbb{D}}$, Maicon Lamb \\ Flores $^{2 \mathbb{D}}$, Bruna Maria Saorin Puton ${ }^{1 \mathbb{D}}$, Eloane Malvessi ${ }^{2}{ }^{\mathbb{D}}$, Eunice Valduga ${ }^{1 \mathbb{D}}$, Jamile Zeni ${ }^{1, * \mathbb{C}}$ \\ 1 Department of Food Engineering, URI - Erechim, Av. 7 of Setembro, 1621, CEP 99709-910, Erechim - RS, Brazil \\ 2 Institute of Biotechnology - University of Caxias of Sul - CEP: 95070-560 - Caxias of Sul - RS - Brazil \\ * Correspondence: jamilezeni@uricer.edu.br;
}

Received: 25.02.2021; Revised: 29.03.2021; Accepted: 3.04.2021; Published: 20.04.2021

\begin{abstract}
Maltobionic acid and its salts are produced by the action of the periplasmic enzymatic complex glucose-fructose oxidoreductase (GFOR), and glicono- $\delta$-lactonase (GL) from Zymomonas mobilis and, for such, cell immobilization is outstanding. Thus, the objective of this work was to immobilize, in situ, Z. mobilis cells containing GFOR/GL in flexible polyurethane foam (PU) in order to produce maltobionic acid. In the immobilization, concentrations of polyurethane and biomass support constituents varied, and the visual aspect of the material immobilized was assessed, its enzymatic activity, immobilization yield, and operational stability. In the maximized immobilization condition, morphological analysis of the support and bioconversion runs were performed. The scanning electron microscopy analysis showed that the microorganism was trapped in the PU ( $7 \mathrm{~g}$ of polyol; $3.5 \mathrm{~g}$ of isocyanate; $0.02 \mathrm{~g}$ of silicone, and $7 \mathrm{~g}$ of biomass). The immobilized material maximum enzymatic activity against glucose was $19.40 \mathrm{U} \mathrm{g}^{-1}$ dry cell, with an immobilization yield of $60.29 \%$ and 15 reuses. In bioconversion, $491.42 \mathrm{mmol} \mathrm{L}^{-1}$ of sodium maltobionate were produced in $47.56 \mathrm{~h}$, with a conversion factor of 0.88 and mass productivity, specific productivity, and specific product formation speed of 2.58 mmol h $\mathrm{h}^{-1} ; 1.81 \mathrm{mmol} \mathrm{g}^{-1} \mathrm{~h}^{-1}$ and $6.25 \mathrm{mmol} \mathrm{g}^{-1} \mathrm{~h}^{-1}$, respectively. This study's results contribute to the production of aldonic acids because it uses scarce information in the area and application potentials.
\end{abstract}

Keywords: aldonic acids; maltobionic acid; sodium maltobionate; kinetic parameters; operational stability.

(c) 2021 by the authors. This article is an open-access article distributed under the terms and conditions of the Creative Commons Attribution (CC BY) license (https://creativecommons.org/licenses/by/4.0/).

\section{Introduction}

Aldonic acids, like maltobionic, glyconic, and lactobionic acids, are obtained by oxidation of an aldose from the aldehyde group, such as maltose, glucose, and lactose, to carboxylic acid, through the enzymatic action of microorganisms or their purified enzymes. This production via enzymatic route presents technological innovations characterized by clean technologies, with less energy consumption and reduced generation of process wastes, when compared to chemical, electrochemical or catalytic pathways, resulting in products with distinct applications [1-10]. Among these enzymes, the periplasmic enzymatic complex glucose-fructose oxidoreductase (GFOR) and glucono-lactonase (GL) from Zymomonas mobilis, responsible for the conversion of aldoses into aldonic acids and fructose into sorbitol, is outstanding [11-14]. 
In a biotechnological process, the biocatalyst preparation (microorganism and enzymes) is very important due to the possibilities of expanding applications through cell immobilization, aiming at greater stability, easiness to separate from the reactional medium, and the possibility of reuse [14-23].

There are cell immobilization reports in the literature aiming at the production of aldonic acids, in limited types of support, like calcium alginate [11, 13, 14, 24-26], magnetic chitosan spheres [27], k-carrageenan [28, 29], polyurethane foam [30] and hollow fiber membrane [31]. However, there is no information on immobilization in situ of Z. mobilis in polyurethane foam. Polyurethane, essentially constituted of two components - polyisocyanates (NCO) and polyols $(\mathrm{OH})$, presents attractive characteristics as support to immobilization, such as resistance, versatility, durability, biostability, and low cost [32-35].

So, this study's objective was to immobilize, in situ, the Z. mobilis containing the periplasmic enzymatic complex GFOR/GL in flexible polyurethane foam and indicate a potential for production of maltobionic acid as salt (sodium maltobionate).

\section{Materials and Methods}

\subsection{Microorganism and cultivation conditions.}

The strain of Z. mobilis ATCC 29191 used in this study was kept in liquid medium suspension, at $4^{\circ} \mathrm{C}$, and was replicated every month, as described by Malvessi et al. [36]. The liquid medium for maintenance, preparation of inoculum, and cultivation (cell growth and enzyme production) comprised 20 (maintenance), 100 (inoculum) and $150 \mathrm{~g} \mathrm{~L}^{-1}$ (production of biomass and enzymes) of glucose, $2.0 \mathrm{~g} \mathrm{~L}^{-1}$ of ammonium sulfate; $1.0 \mathrm{~g} \mathrm{~L}^{-1}$ of heptahydrate magnesium sulfato; $3.5 \mathrm{~g} \mathrm{~L}^{-1}$ of monobasic potassium phosphate; $0.01 \mathrm{~g} \mathrm{~L}^{-1}$ of heptahydrate iron sulfate; $7.5 \mathrm{~g} \mathrm{~L}^{-1}$ of crude yeast extract (Prodex $\mathrm{Lac}^{\circledR}$ ). For inoculum preparation, $5 \mathrm{~g} \mathrm{~L}^{-1}$ calcium carbonate was added to the medium for $\mathrm{pH}$ control. Glucose and calcium carbonate $\left(\mathrm{CaCO}_{3}\right)$ solution were separately sterilized and added to the medium before inoculation. The sterilization of nutrients and glucose solutions was made in an autoclave at $121^{\circ} \mathrm{C}$, for $15 \mathrm{~min}$. The culture's maintenance and activation were made in tubes with $10 \%$ bacterial suspension and incubated at $30^{\circ} \mathrm{C}$ in the stove (Biomatic, Brasil), for $12 \mathrm{~h}$, without stirring. The inoculum preparation was made in $500 \mathrm{~mL}$ anaerobic glass bottle, with filters for release of carbon gas, containing $315 \mathrm{~mL}$ of medium, $90 \mathrm{~mL}$ of glucose solution, and $45 \mathrm{~mL}$ of the previously activated culture, and was kept at $30^{\circ} \mathrm{C}, 200 \mathrm{rpm}$ in an orbital shaker (Excella E25R, New Brunswick Scientific Co., INC, USA), for approximately $10 \mathrm{~h}$. The cell concentration of this inoculum was estimated, by an indirect method, by optical density at $560 \mathrm{~nm}$, resulting in a linear relation with dry cells' mass concentration [36].

The cultivation for cell growth and production of the periplasmic enzymatic complex GFOR/GL was made in batches, in bench jacketed reactor (B. Braun Biotech International Biostat $^{\circledR} \mathrm{B}$, Holanda), with a total volume of $2 \mathrm{~L}$ and service volume of $1.5 \mathrm{~L}$, a mechanical stirring of $450 \mathrm{rpm}$ and $30^{\circ} \mathrm{C}$, kept with the assistance of ultra thermostatic bath (Nova Ética, Brasil). The anaerobiosis was kept with the addition of gaseous nitrogen to the reactor in the first 45 minutes of cultivation and the $5.4 \mathrm{pH}$ by adding sodium hydroxide $(\mathrm{NaOH}) 5 \mathrm{~mol} \mathrm{~L}-1$, with $\mathrm{pH}$ controller (DosaTronic pH 2900, Provitec, Brasil) attached to a peristaltic pump (DosaMini 100, Provitec, Brasil). The cell mass was collected in the medium and centrifuged (Centrifuge MPW-351R, MPW ${ }^{\circledR}$ Med. Instruments, Poland) for $10 \mathrm{~min}$ at $6000 \mathrm{rpm}$, and cell concentration, in dry mass, was determined by gravimetry [36]. 


\subsection{Immobilization in situ of $Z$. mobilis in flexible polyurethane (PU).}

In the immobilization in situ, first, runs were made varying the amounts of polyol (10 to $20 \mathrm{~g}$ ) (Dim Clay, Brasil), isocyanate (3 to $7 \mathrm{~g}$ ) (Dim Clay, Brasil), silicone (0 to $0.04 \mathrm{~g}$ ) (Tasca Estofados e Cia, Brasil), amount of biomass (0.5 to $10 \mathrm{~g}$ ) and biomass concentration (70, 140 and $210 \mathrm{~g} \mathrm{~L}^{-1}$ ). The cell material (without previous treatment, only diluted in different concentrations with distilled water after centrifugation and determination of dry mass) and the silicone were added to the polyol and homogenized for the later addition of isocyanate to the mix. After expansion and foam formation, it remained at rest for $24 \mathrm{~h}$ to be cured at room temperature $\left(22^{\circ} \mathrm{C} \pm 2{ }^{\circ} \mathrm{C}\right)$. They were later fractionated in cubes with $5 \mathrm{~mm}$ of edge or in particulate dimension, with grain size ranging from 0.850 to $0.355 \mathrm{~mm}$ (standardized in 20 and 42 mesh - Bertel Indústria Metalurgica Ltda, Brasil), treated with glutaraldehyde $0.5 \%$ (w/v) for 15 min under magnetic stirring, followed by two washes in distilled water, under magnetic stirring, for $15 \mathrm{~min}$, to remove the glutaraldehyde. After removing excess water, the foams were dried in the hood (Quimis 0216-21, Brasil) with airflow on and in contact with filter paper (JProlab, Brasil) for $24 \mathrm{~h}$. This procedure was required to inhibit the cells' metabolism without affecting the enzymatic activity [13] and removing unbound cells/enzymes. This treatment was also made in free Z. mobilis cells subject to the enzymatic activity runs. Those immobilized were kept in the closed recipient at $4^{\circ} \mathrm{C} \pm 2^{\circ} \mathrm{C}$, until the moment of use.

Those immobilized were assessed as to the visual aspect of the foams, mass loss, and enzymatic activity $\left(\mathrm{U} \mathrm{g} \mathrm{g}^{-1}\right.$ dry cell), in glucose and fructose $0.7 \mathrm{~mol} \mathrm{~L}{ }^{-1}$, at $39^{\circ} \mathrm{C}, \mathrm{pH} 6.4$ and $4 \mathrm{~g}$ of immobilized material.

The criteria for assessing the visual aspect of the flexible polyurethane foams with $Z$. mobilis immobilized in situ were shrinkage, accumulation of internal or external biomass, unevenness, high porosity, aspect of scale, dry and/or rigid. Foams that did not present these characteristics were classified as "Acceptable" for use and those that presented one or more of them were classified as "Not acceptable" for use and disposed of.

The loss of mass of the support, in cubes, was assessed before and after the treatment in glutaraldehyde $0.5 \%$, keeping the support in the airflow hood (Quimis 0216-21, Brasil) during $24 \mathrm{~h}$.

\subsubsection{Immobilization yield.}

The immobilization yield (IY) was determined by the ratio between the immobilized $Z$. mobilis (Uimmobilized) GFOR/GL enzymatic activity and the free bacteria (Ufree) GFOR/GL enzymatic activity, and the result is expressed in percentage (\%) [32], according to Equation 1.

$$
\mathrm{IY}=\frac{\mathrm{U}_{\text {immobilized }}}{\mathrm{U}_{\text {free }}} \times 100
$$

2.2.2. Morphological analysis of the support and the immobilized material.

The support and the immobilized material were analyzed by scanning electron microscopy (SEM). The samples' preparation occurred with the particulate immobilized material fixation or fixation of a fragment of foam without microorganism on metallic support, using double-sided adhesive carbon tape and coated in metallizer (SC 7620, Quorum, UK) with a thin layer of gold $(20 \mathrm{~nm}$ ), under vacuum. The samples were analyzed in SEM (ZEISS - EVO LS 25, Germany), with an expansion of 107, 5,000, and 10,000 times and voltage $10 \mathrm{kV}$. 


\subsection{Enzyme activity.}

The enzymatic activity determination was conducted according to the methodology proposed by Malvessi et al. [36], with modifications from an equimolar solution $0.7 \mathrm{~mol} \mathrm{~L}^{-1}$ of glucose and fructose, $4 \mathrm{~g} \mathrm{~L}^{-1}$ of free $Z$. mobilis cells, the reaction in $100 \mathrm{~mL}$ of service volume, for $1 \mathrm{~h}$, and using $\mathrm{NaOH} 1 \mathrm{~mol} \mathrm{~L}^{-1}$ solution for $\mathrm{pH}$ control at 6.4, in order to confirm the production of the enzymatic complex (GFOR/GL) in the biomass under cultivation in the bioreactor.

For the tests with the microorganism immobilized in foam, the same procedures were conducted, however using $4 \mathrm{~g}$ of immobilized support, a reaction in $200 \mathrm{~mL}$ of service volume, for $1 \mathrm{~h}$ and $\mathrm{NaOH} 0.1-0.35 \mathrm{~mol} \mathrm{~L}^{-1}$. The $\mathrm{NaOH}$ solution concentration used depended on the reaction rate.

The glucose substrate was chosen for the determination of enzymatic activity because it is the aldose with higher affinity with the GFOR enzyme, followed by maltose, galactose, and lactose $[12,37]$ and is commonly used as a reference for the effectuation of Z. mobilis biomass production and its enzymatic complex [11, 13, 26, 38].

The unit for enzymatic activity was defined as the amount of glyconic acid, in mmol, formed per hour and per gram of dry cell, containing the GFOR/GL enzymatic complex GFOR/GL ( $\mathrm{mmol} \mathrm{h}^{-1} \mathrm{~g}^{-1}$ dry cell $=\mathrm{U} \mathrm{g}^{-1}$ dry cell), and these values estimated by the slope of the line obtained by the relation between time and volume consumed of the base, and this volume is multiplied by the $\mathrm{NaOH}$ concentration used to neutralize the acid formed and control the $\mathrm{pH}$ in $6.4[11,12,26]$.

\subsection{Operational stability of the immobilized material.}

The enzyme stability of Z. mobilis GFOR/GL during the immobilization runs was assessed by reuse, in repeated cycles of $1 \mathrm{~h}$, of enzyme activity in glucose and fructose $(0.7$ mol $\left.\mathrm{L}^{-1}\right)$, under the same operational conditions as those of enzyme activity runs $\left(39^{\circ} \mathrm{C}, \mathrm{pH}\right.$ 6.4). In the interval between each batch, the flexible polyurethane foam immobilized with $Z$. mobilis was removed from the medium, washed - for removal of residual substrate in the foam, with $350 \mathrm{~mL}$ of distilled water, under magnetic stirring for $5 \mathrm{~min}$, filtered in filter paper (JProlab, Brasil) using a vacuum pump (Marte ${ }^{\circledR}$ model 131, Brasil) and added to the new medium for a new measurement. This procedure was conducted in each batch until the obtention of $50 \%$ of initial enzymatic activity.

\subsection{Bioconversion in sodium maltobionate.}

To assess the potential for production of maltobionoic acid as sodium maltobionate salt, bioconversion batches were performed using the immobilized material. For such, equimolar concentrations of maltose and fructose at $0.7 \mathrm{~mol} \mathrm{~L}^{-1}$ were used as a substrate, in the jacketed reactor with $500 \mathrm{~mL}$ of total volume and $200 \mathrm{~mL}$ of service volume, at $39^{\circ} \mathrm{C}$, kept with ultrathermostat bath (Nova Ética, Brazil) and pH 6.4 controlled with $\mathrm{NaOH} 2.5 \mathrm{~mol} \mathrm{~L}^{-1}$ solution (DosaTronic pH 2900, Provitec, Brazil) attached to a peristaltic pump (DosaMini 100, Provitec, Brazil), and magnetic stirring [26]. Biomass concentration of $7 \mathrm{~g}_{\mathrm{dry}} \mathrm{L}^{-1}$ reaction medium and immobilized material was kept fixed as particulates in these runs. The reaction time was established by converting $90 \%$ maltose into sodium maltobionate, observed by the base consumption. 
2.5.1. Kinetic and stoichiometric parameters of bioconversion.

The maltobionic acid (as sodium salt) and sorbitol were formed in an equimolar base during the bioconversion process, and they were the only products of the reaction bio catalyzed by GFOR/GL enzymes. Maltose and fructose substrates were consumed in the same proportion. Thus, during the bioconversion, substracts and products were quantified by the indirect method by determining the volume and concentration of the base added $(\mathrm{NaOH})$ to control the reaction $\mathrm{pH}[12,39]$, and equivalence of this method was observed by determination via liquid chromatography [13].

To determine the amount of product formed and residual substrate during bioconversion, Equations 2 and 3, respectively, were used.

$$
\begin{aligned}
& C_{P}=\frac{V_{b} \cdot M \cdot M_{M}}{\left(V_{T}+V_{b}\right)} \\
& C_{S, f}=C_{S, i}-\frac{V_{b} \cdot M \cdot M_{M S}}{\left(V_{\tau}+V_{b}\right)}
\end{aligned}
$$

Where, $\mathrm{C}_{\mathrm{p}}$ is concentration of formed product $\left(\mathrm{g} \mathrm{L}^{-1}\right)$; $\mathrm{Cs}_{\mathrm{s}, \mathrm{f}}$ is concentration of residual substract $\left(\mathrm{g} \mathrm{L}^{-1}\right) ; \mathrm{V}_{\mathrm{b}}$ is base volume $(\mathrm{mL}) ; \mathrm{M}$ is base concentration $\left(\mathrm{mol} \mathrm{L}^{-1}\right)$; $\mathrm{M}_{\mathrm{M}}$ : molar mass of the product (maltobionic acid $=358.3 \mathrm{~g} \mathrm{~mol}^{-1}$; sodium maltobionate $=380.3 \mathrm{~g} \mathrm{~mol}^{-1}$ ); $\mathrm{V}_{\mathrm{T}}$ is total volume of the bioconversion; $\mathrm{Cs}_{\mathrm{s}, \mathrm{i}}$ : concentration of initial substract $\left(\mathrm{g} \mathrm{L}^{-1}\right)$; and $\mathrm{M}_{\mathrm{MS}}$ is substract molar mass (maltose $=360 \mathrm{~g} \mathrm{~mol}^{-1}$ ).

The factor for conversion of substrate into the product (Y $\mathrm{P} / \mathrm{SO})$ was determined by dividing the mmol number of the product (sodium maltobionate) formed by the mmol number of the substrate (maltose) in the initial solution.

Mass productivity ( $\mathrm{P}, \mathrm{mmol}$ of product per hour) was calculated by dividing the product mmol number by the processing time.

Specific productivity (q, mmol of product per gram of dry cell per hour) was determined by dividing the mass productivity by the cell mass used in the bioconversion runs.

And the specific product formation speed $\left(\mu_{\mathrm{p} \text {.max }}, \mathrm{mmol}\right.$ of product per gram of dry cell per hour) was determined, deriving the curve adjusted for mmol of the product as a function of time and dividing this result by the mass of $Z$. mobilis cells ( $\left.1.4 \mathrm{~g}_{\text {dry cell }}\right)$ used in the experiment.

\subsection{Statistical analysis.}

Results $(\mathrm{n}=3)$ were statistically treated by variance analysis - ANOVA followed by mean differences with Tukey test, and assistance of software Statistic 5.0, with a significance level of $95 \%$ of confidence.

\section{Results and Discussion}

The highest enzymatic activity was $8.01 \mathrm{U} \mathrm{g}^{-1}$ dry cell (Table 1) using $14 \mathrm{~g}$ of polyol reagent, $6 \mathrm{~g}$ of isocyanate reagent, $0.04 \mathrm{~g}$ of silicone, and $10 \mathrm{~g}$ of biomass with a concentration of $210 \mathrm{~g} \mathrm{~L}^{-1}$, presenting foam visual aspect as acceptable. The results show that it was possible to immobilize Z. mobilis in situ in flexible polyurethane foam with GFOR/GL enzymatic activity.

While treating the PU cubes with $5 \mathrm{~mm}$ of edge with glutaraldehyde mass loss (Table 2) of up to $30 \%$ was observed, due to the support low mechanical resistance when cell mas was incorporated, suggesting compromise in the reuse of the immobilized material in cubes and indicating as an alternative the use of foam as particulates. 
Table 1. Enzymatic activity and visual aspect of Z. mobilis immobilized material in situ, with different concentrations of polyol, isocyanate, silicone, and biomass.

\begin{tabular}{|c|c|c|c|c|c|c|c|}
\hline Runs & $\begin{array}{c}\text { Polyol } \\
\text { (g) }\end{array}$ & $\begin{array}{l}\text { Isocyanate } \\
\text { (g) }\end{array}$ & $\begin{array}{l}\text { Silicone } \\
\text { (g) }\end{array}$ & $\begin{array}{l}\text { Biomass } \\
(\mathrm{g})\end{array}$ & $\begin{array}{c}\text { Biomass of concentration } \\
\left(\mathrm{g} \mathrm{L}^{-1}\right)\end{array}$ & Visual aspect & $\begin{array}{c}\text { Enzymatic activity } \\
\left(\mathbf{U ~ g ~}^{-1} \text { dry cell }\right)\end{array}$ \\
\hline 1 & 10 & 3 & 0 & 1 & 70 & Acceptable & n.d. \\
\hline 2 & 10 & 3 & 0 & 1 & 70 & Acceptable & n.d. \\
\hline 3 & 10 & 3 & 0 & 1 & 70 & Acceptable & n.d. \\
\hline 4 & 10 & 3 & 0 & 1 & 70 & Acceptable & n.d. \\
\hline 5 & 10 & 3 & 0 & 2 & 70 & Acceptable & n.d. \\
\hline 6 & 10 & 3 & 0 & 3 & 70 & Not acceptable & n.d. \\
\hline 7 & 10 & 3 & 0 & 1 & 140 & Not acceptable & n.d. \\
\hline 8 & 10 & 3 & 0 & 1 & 140 & Acceptable & n.d. \\
\hline 9 & 10 & 3 & 0 & 0.5 & 210 & Acceptable & n.d. \\
\hline 10 & 10 & 3 & 0 & 0.75 & 210 & Not acceptable & n.d. \\
\hline 11 & 10 & 3 & 0 & 1 & 210 & Not acceptable & n.d. \\
\hline 12 & 15 & 4.50 & 0 & 1 & 210 & Acceptable & n.d. \\
\hline 13 & 15 & 4.50 & 0 & 1 & 210 & Acceptable & n.d. \\
\hline 14 & 15 & 4.50 & 0 & 2 & 210 & Acceptable & n.d. \\
\hline 15 & 15 & 4.50 & 0 & 2.5 & 210 & Acceptable & n.d. \\
\hline 16 & 15 & 4.50 & 0 & 3 & 210 & Not acceptable & n.d. \\
\hline 17 & 20 & 6 & 0 & 3 & 210 & Acceptable & 0.29 \\
\hline 18 & 20 & 6 & 0 & 4 & 210 & Acceptable & 0.67 \\
\hline 19 & 20 & 6 & 0 & 5 & 210 & Acceptable & 1.05 \\
\hline 20 & 20 & 6 & 0 & 6 & 210 & Not acceptable & n.d. \\
\hline 21 & 19 & 6 & 0 & 6 & 210 & Not acceptable & n.d. \\
\hline 22 & 18 & 6 & 0 & 6 & 210 & Not acceptable & n.d. \\
\hline 23 & 17 & 6 & 0 & 6 & 210 & Not acceptable & n.d. \\
\hline 24 & 16 & 6 & 0 & 6 & 210 & Not acceptable & n.d. \\
\hline 25 & 15 & 6 & 0 & 6 & 210 & Not acceptable & n.d. \\
\hline 26 & 14 & 6 & 0 & 6 & 210 & Not acceptable & n.d. \\
\hline 27 & 15 & 6 & 0.02 & 6 & 210 & Acceptable & 2.68 \\
\hline 28 & 15 & 7 & 0.04 & 6 & 210 & Acceptable & 1.21 \\
\hline 29 & 15 & 6 & 0.01 & 8 & 210 & Not acceptable & n.d. \\
\hline 30 & 15 & 6 & 0.02 & 8 & 210 & Acceptable & 7.82 \\
\hline 31 & 14 & 6 & 0.02 & 8 & 210 & Not acceptable & n.d. \\
\hline 32 & 14 & 6 & 0.02 & 9 & 210 & Acceptable & 3.87 \\
\hline 33 & 14 & 6 & 0,04 & 9 & 210 & Acceptable & 7.60 \\
\hline 34 & 14 & 6 & 0.02 & 10 & 210 & Not acceptable & n.d. \\
\hline 35 & 14 & 6 & 0.03 & 10 & 210 & Acceptable & 6.10 \\
\hline 36 & 14 & 6 & 0.04 & 10 & 210 & Acceptable & 8.01 \\
\hline 37 & 13 & 6 & 0.03 & 10 & 210 & Not acceptable & n.d. \\
\hline 38 & 12 & 6 & 0.03 & 10 & 210 & Not acceptable & n.d. \\
\hline
\end{tabular}

n.d. Enzyme activity not detected

Dimension: $5 \mathrm{~mm}$ edge cubes.

Table 3 presents the results for enzymatic activity, immobilization yield, and operational stability of in situ immobilized material characteristics. Enzymatic activities ranged from 5.31 to $18.13 \mathrm{U} \mathrm{g}^{-1}$ dry cell (1.33 and $4.52 \mathrm{U} \mathrm{g}^{-1}$ immobilized), and operational stability was up to 15 reuses (mean residual activity of $8.84 \mathrm{U} \mathrm{g}^{-1}$ dry cell); that is, it was possible to use the immobilized material in up to 16 operational cycles, keeping up to $50 \%$ of the initial enzymatic activity.

Enzymatic activities in runs (Table 3) were lower than those observed when free microorganisms/enzymes were used $\left(31.80 \mathrm{U} \mathrm{g}^{-1}\right.$ dry cell). This behavior was also observed by other authors [11, 12, 26, 31, 40-42] and can be caused by diffusional effects and/or increase in the resistance to the mass transfer imposed by the support used, or, also, due to conformational effects of the enzyme or adverse conditions in the support micro-environment. However, the lowest enzymatic activity would be compensated by the possibility of reuse of the immobilized material. 
Table 2. PU ( $5 \mathrm{~mm}$ ) cubes' mass loss of immobilized material during treatment with glutaraldehyde $0.5 \%$.

\begin{tabular}{|c|c|c|c|c|c|}
\hline Runs & $\begin{array}{c}\text { Polyol } \\
\text { (g) }\end{array}$ & $\begin{array}{c}\text { Isocyanate } \\
\text { (g) }\end{array}$ & $\begin{array}{c}\text { Silicone } \\
(\mathrm{g})\end{array}$ & $\begin{array}{c}\text { Biomass } \\
(\mathrm{g})\end{array}$ & $\begin{array}{c}\text { Mass loss } \\
(\%)\end{array}$ \\
\hline 1 & 7 & 3 & 0 & 0 & $1.71^{\mathrm{i}} \pm 0.07$ \\
\hline 2 & 10 & 3 & 0.01 & \multirow{8}{*}{1} & $11.14^{\mathrm{e}} \pm 0.44$ \\
\hline 3 & 10 & 3 & 0.02 & & $8.78^{\mathrm{f}} \pm 0.35$ \\
\hline 4 & 10 & 3.5 & 0.01 & & $6.06^{\mathrm{h}} \pm 0.24$ \\
\hline 5 & 10 & 3.5 & 0.02 & & $7.74^{\mathrm{g}} \pm 0.31$ \\
\hline 6 & 10 & 3.75 & 0.01 & & n.d. \\
\hline 7 & 10 & 3.75 & 0.02 & & $6.47^{\mathrm{h}} \pm 0.26$ \\
\hline 8 & 9 & 3 & 0.01 & & $8.28^{\mathrm{f}} \pm 0.33$ \\
\hline 9 & 9 & 3.5 & 0.02 & & n.d. \\
\hline 10 & 9 & 3 & 0.01 & \multirow{6}{*}{3} & $19.13^{b} \pm 0.76$ \\
\hline 11 & 9 & 3.5 & 0.02 & & $15.85^{c} \pm 0.63$ \\
\hline 12 & 8 & 3 & 0.01 & & $12.95^{\mathrm{d}} \pm 0.52$ \\
\hline 13 & 8 & 3 & 0.02 & & $21.43^{b} \pm 0.86$ \\
\hline 14 & 8 & 3.5 & 0.01 & & $12.74^{\mathrm{d}} \pm 0.51$ \\
\hline 15 & 8 & 3.5 & 0.02 & & $9.49^{f} \pm 0.38$ \\
\hline 16 & 14 & 6 & 0.04 & 10 & $30.16^{\mathrm{a}} \pm 1.21$ \\
\hline
\end{tabular}

* mean \pm standard deviation followed by equal letters indicates that there is no significant difference $(\mathrm{p}<0.05)$ Tukey's test.

Fixed variables: $5 \mathrm{~g}$ of biomass at a concentration of $210 \mathrm{~g} \mathrm{~L}^{-1}$ and the cubes' dimension with $5 \mathrm{~mm}$ edge. n.d. - not determined due to the unacceptable visual aspect of the asset.

Table 3. Enzyme activity, immobilization yield, and operational stability of the PU immobilized.

\begin{tabular}{|c|c|c|c|c|c|}
\hline Runs & $\begin{array}{c}\text { Formulation } \\
\text { (polyol/isocyanate/ silicone) } \\
(\mathrm{g})\end{array}$ & $\begin{array}{c}\text { Enzymatic } \\
\text { activity } \\
\left(\mathbf{U ~ g}^{-1} \text { imobilized }\right) \\
\end{array}$ & $\begin{array}{l}\text { Immobilization } \\
\text { yield } \\
(\%)\end{array}$ & $\begin{array}{c}\text { Enzymatic } \\
\text { activity } \\
\left(\mathbf{U ~ g}^{-1} \text { imobilized }\right)\end{array}$ & $\begin{array}{c}\text { Operational } \\
\text { stability } \\
\text { (reuses) }\end{array}$ \\
\hline 1 & $6 / 3 / 0.01$ & n.d. & n.d. & n.d. & n.d. \\
\hline 2 & $6 / 3.50 / 0.02$ & n.d. & n.d. & n.d. & n.d. \\
\hline 3 & $7 / 3 / 0.01$ & $18.13^{\mathrm{a}} \pm 2.55$ & $56.52^{\mathrm{a}} \pm 2.98$ & $4.52^{\mathrm{a}} \pm 0.64$ & $16^{\mathrm{a}}$ \\
\hline 4 & $7 / 3 / 0.02$ & n.d. & n.d. & n.d. & n.d. \\
\hline 5 & $7 / 3.50 / 0.01$ & $11.49^{\mathrm{abc}} \pm 0.38$ & $37.06^{b} \pm 1.73$ & $2.87^{\mathrm{abc}} \pm 0.13$ & $9^{\text {cd }}$ \\
\hline 6 & $7 / 3.50 / 0.02$ & $16.35^{\mathrm{a}} \pm 0.66$ & $51.48^{\mathrm{a}} \pm 1.22$ & $4.08^{\mathrm{a}} \pm 0.23$ & $16^{\mathrm{a}}$ \\
\hline 7 & $7 / 3.75 / 0.01$ & $9.23^{\mathrm{bc}} \pm 0.31$ & $29.77^{b} \pm 1.41$ & $2.30^{\mathrm{bc}} \pm 0.11$ & $9^{d}$ \\
\hline 8 & $7 / 3.75 / 0.02$ & $9.03^{\mathrm{bc}} \pm 0.47$ & $28.41^{\mathrm{bc}} \pm 1.12$ & $2.25^{\mathrm{bc}} \pm 0.16$ & $11^{\mathrm{b}}$ \\
\hline 9 & $7 / 4 / 0.01$ & n.d. & n.d. & n.d. & n.d. \\
\hline 10 & $7 / 4 / 0.02$ & $5.31^{\mathrm{c}} \pm 0.62$ & $16.69^{c} \pm 2.20$ & $1.33^{\mathrm{c}} \pm 0.22$ & n.d. \\
\hline 11 & $8 / 3 / 0.01$ & $12.47^{\mathrm{ab}} \pm 1.88$ & $38, .18^{\mathrm{b}} \pm 5.69$ & $3.11^{\mathrm{ab}} \pm 0.66$ & $10^{\mathrm{bc}}$ \\
\hline 12 & $8 / 3.50 / 0.02$ & $17.01^{\mathrm{a}} \pm 1.81$ & $52.20^{\mathrm{a}} \pm 4.48$ & $4.25^{\mathrm{a}} \pm 0.64$ & $15^{\mathrm{a}}$ \\
\hline 13 & $9 / 3 / 0.01$ & n.d. & n.d. & n.d. & n.d. \\
\hline 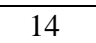 & $9 / 3.50 / 0.02$ & n.d. & n.d. & - & n.d. \\
\hline
\end{tabular}

* Mean (standard deviation); different lower case letters in the same column correspond to the statistical difference at the $5 \%$ level by the Tukey test.

Fixed variables: $5 \mathrm{~g}$ of biomass at a concentration of $210 \mathrm{~g} \mathrm{~L}^{-1}$ and the PU dimension with particles from 0.850 to $0.355 \mathrm{~mm}$.

n.d. - not determined by the unacceptable visual aspect of the asset.

Considering the results obtained (Table 3), some hypotheses are suggested: (I) with the increase in the amount of isocyanate, the enzymatic activities obtained were lower, probably due to the reaction temperature increase and possible denaturation of enzymes; (II) for greater amounts of silicone, keeping the other reagents, there is a tendency to a higher number of reuses because the greater the amount of silicone, the fewer are the foam pores, reducing losses of cells/enzymes that could be weakly adhered to the support; (III) excess of silicone in the formulation results in foam shrinkage and this is directly proportional to the amount of silicone added; and (IV) excess or lack of any reagent in the formulation make the immobilized foam aspect unacceptable for use, due to porosity, texture or unevenness throughout the foam.

Silicone was essential in the proposed immobilization. According to Vilar [43], in the formation of low-density polyurethane foams, the silicone surfactant acts in dispersing the 
formulation reagents and stabilizing growing foam cells. Additionally, it assists in the nucleation by reducing surface tension, enabling the air's introduction to form the foam cells' nuclei. The appropriate use of silicone surfactant promotes stability, making more difficult the coalescence of bubbles, and its increase results in a reduction of the foam cells' size and increases in their number. On the other hand, the excess stabilizes the system and can avoid these cells' opening.

During reuse tests (Table 3), support losses were also observed in the filtration stage. This was observed by weighing the filters used, with average losses of up to $0.05 \mathrm{~g}$ per cycle or total average losses between 0.09 and $0.3 \mathrm{~g}$ of immobilized material per sample. These data indicate that the reduction in enzymatic activity at each cycle could have been caused by the reduction in the amount of support as well, and, therefore, of cells/enzymes.

The Z. mobilis immobilized and enzyme complex's reuse up to 15 times suggests that the microorganism has strongly adhered to the support. This cell immobilization could be observed by the SEM images, where it was possible to notice the presence of microbial cells, rod-shaped, in the particulate immobilized support (Figure 1b, c), which were not observed in the standard foam (Figure 1a).

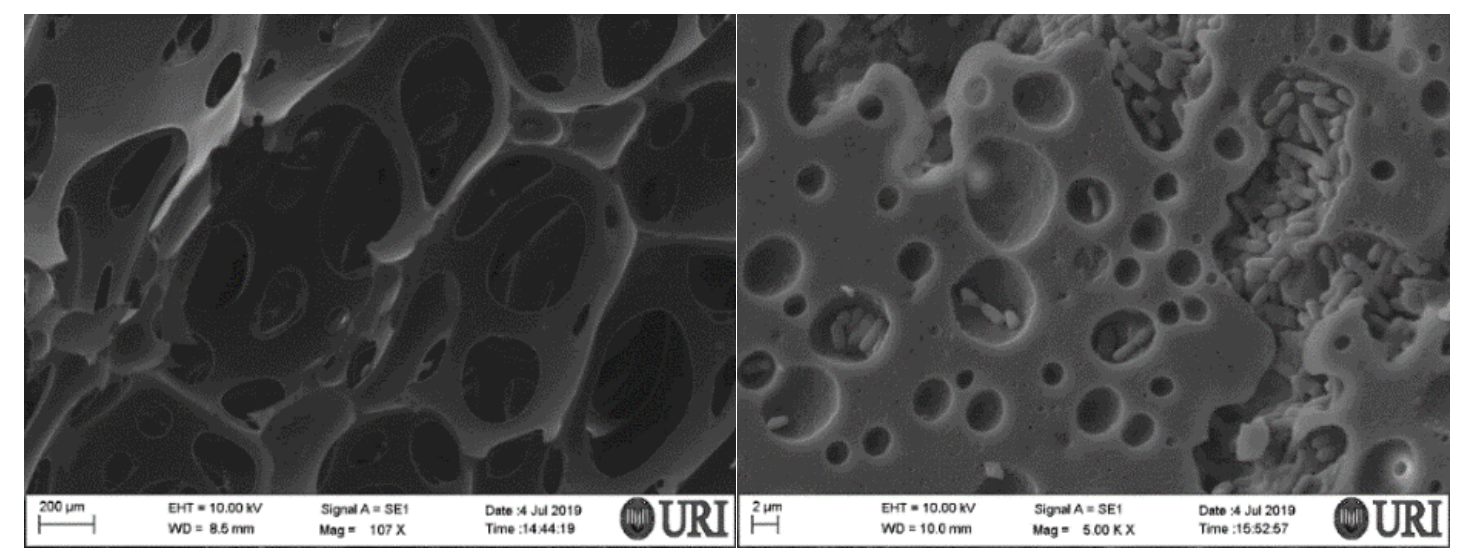

(a)

(b)

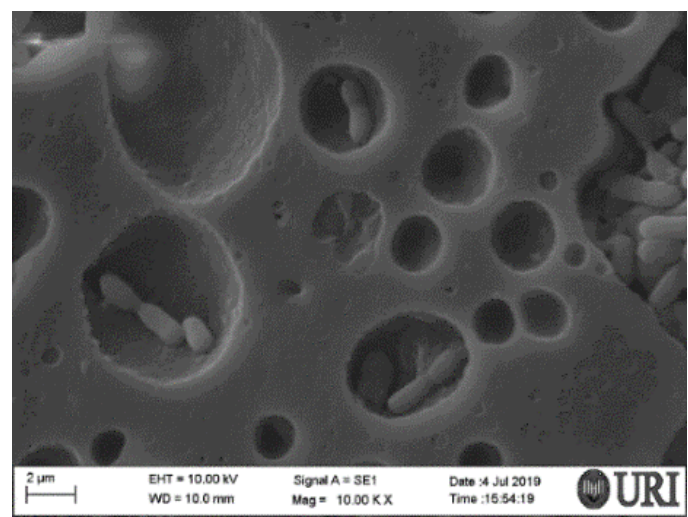

(c)

Figure 1. Scanning electron microscopy of (a) standard flexible polyurethane foam (107 x), particulate flexible polyurethane foam immobilized with Z. mobilis and enzyme complex in situ (b) 5,000 x and (c) 10,000x.

Results (Table 3) also showed that incorporating $5 \mathrm{~g}$ of biomass proved to be promising. However, additional studies were required to determine the maximum amount of biocatalyst immobilized with this method, aiming at obtaining a higher concentration of products in the bioconversion stage. The visual aspect and the result of immobilized materials prepared with different biomass amounts are presented in Figure 2 and Table 4. The enzymatic activity per amount of dry cell using from 5 to $9 \mathrm{~g}$ of biomass (runs 3-7), the enzymatic activity per amount 
of immobilized material using from 7 to $10 \mathrm{~g}$ of biomass (runs 5-8), and the operational stability (runs 3-5) did not differ statistically ( $\mathrm{p}<0.05)$. It can also be observed that with an increase in biomass amount $(8,9$, and $10 \mathrm{~g})$ the immobilized material aspect was humid, brittle, and with gradual shrinkage, so they are not indicated for use (Figure $2 \mathrm{f}, \mathrm{g}, \mathrm{h}$ ). Besides, with the use of samples prepared with $8 \mathrm{~g}$ or more of biomass (runs 6-8), instability was observed during the immobilization stage, and so they are more sensitive to environmental conditions, resulting, in some runs, a harmful shrinkage during the cure period, and so, they were disposed of.
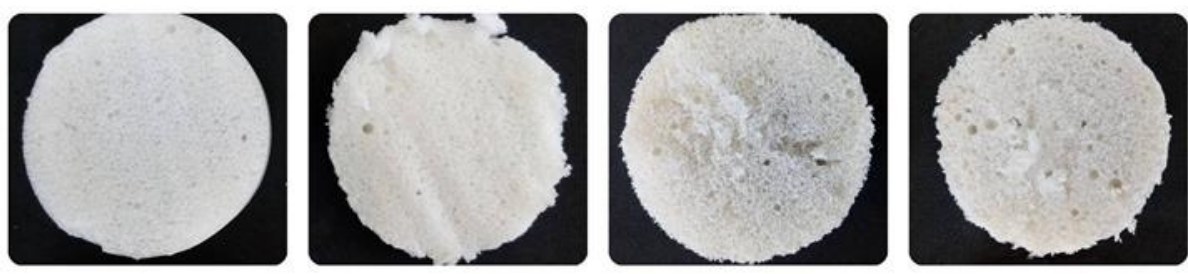

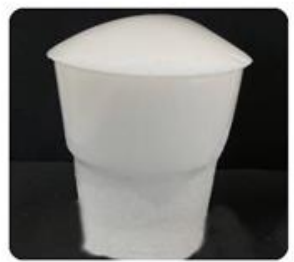

(a)
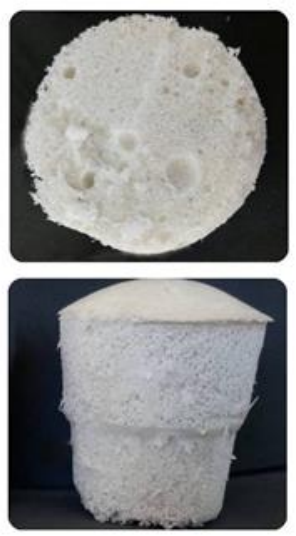

(e)

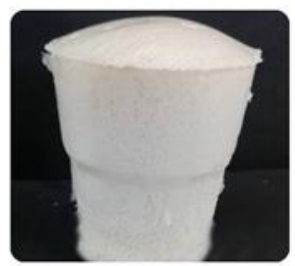

(b)
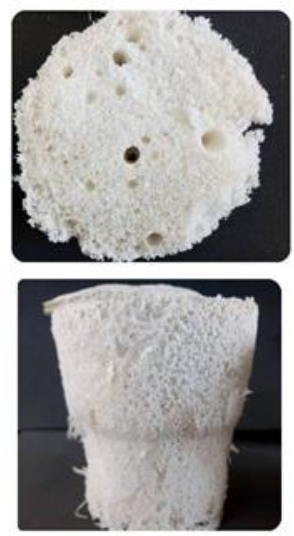

(f)

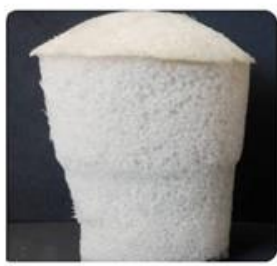

(c)
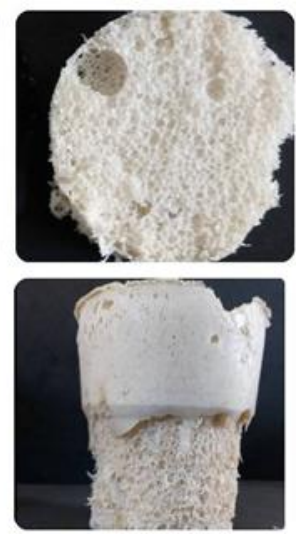

(g)

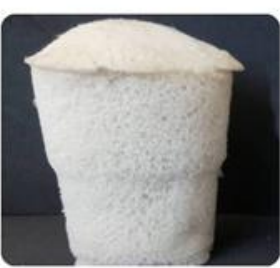

(d)

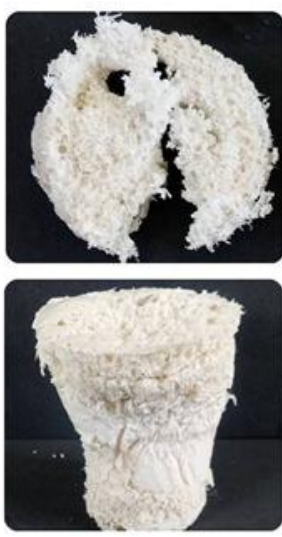

(h)

Figure 2. Visual aspect of Z. mobilis in situ immobilized materials, varying the biomass $\left(210 \mathrm{~g} \mathrm{~L}^{-1}\right)$ in (a) 1 , (b) 3, (c) 5, (d) 6, (e) 7, (f) 8, (g) 9 and (h) 10 g, respectively.

Table 4. Enzymatic activity, immobilization yield, and operational stability of immobilized materials.

\begin{tabular}{c|c|c|c|c|c|c}
\hline Runs & $\begin{array}{c}\text { Biomass } \\
(\mathbf{g})\end{array}$ & $\begin{array}{c}\text { Formulaçtion } \\
(\mathbf{p o l y o l} / \text { isocyanate/ silicone) } \\
(\mathbf{g})\end{array}$ & $\begin{array}{c}\text { Enzymatic } \\
\text { activity } \\
\left(\mathbf{U} \mathbf{g}^{-1} \mathbf{d r y} \text { cell }\right)\end{array}$ & $\begin{array}{c}\text { Immobilization } \\
\text { yield } \\
(\mathbf{\%})\end{array}$ & $\begin{array}{c}\text { Enzymatic } \\
\text { activity } \\
\left(\mathbf{U ~ g}^{-1} \text { imobilized }\right)\end{array}$ & $\begin{array}{c}\text { Operational } \\
\text { stability } \\
(\text { reuses })\end{array}$ \\
\hline 1 & 1 & $10 / 3.50 / 0.02$ & $1.04^{\mathrm{c}} \pm 0.30$ & $3.23^{\mathrm{c}} \pm 0.94$ & $0.01^{\mathrm{d}} \pm 0.01$ & n.d. \\
\hline 2 & 3 & $9 / 3.50 / 0.02$ & $3.16^{\mathrm{c}} \pm 0.40$ & $9.81^{\mathrm{c}} \pm 1.25$ & $0.13^{\mathrm{d}} \pm 0.02$ & n.d. \\
\hline 3 & 5 & $8 / 3.50 / 0.02$ & $17.01^{\mathrm{ab}} \pm 2.56$ & $52.86^{\mathrm{ab}} \pm 7.96$ & $1.07^{\mathrm{c}} \pm 0.17$ & $15^{\mathrm{a}}$ \\
\hline 4 & 6 & $7.50 / 3.50 / 0.02$ & $19.42^{\mathrm{a}} \pm 0.33$ & $60.34^{\mathrm{a}} \pm 1.03$ & $1.40^{\mathrm{bc}} \pm 0.07$ & $16^{\mathrm{a}}$ \\
\hline 5 & 7 & $7 / 3.50 / 0.02$ & $19.40^{\mathrm{a}} \pm 0.42$ & $60.29^{\mathrm{a}} \pm 1.31$ & $1.61^{\mathrm{ab}} \pm 0.04$ & $16^{\mathrm{a}}$ \\
\hline 6 & 8 & $6.50 / 3.50 / 0.02$ & $17.51^{\mathrm{ab}} \pm 0.75$ & $54.42^{\mathrm{ab}} \pm 2.32$ & $1.61^{\mathrm{ab}} \pm 0.07$ & n.d. \\
\hline 7 & 9 & $6 / 3.50 / 0.02$ & $18.45^{\mathrm{ab}} \pm 1.52$ & $57.33^{\mathrm{ab}} \pm 4.72$ & $1.85^{\mathrm{a}} \pm 0.14$ & n.d. \\
\hline 8 & 10 & $5.50 / 3.50 / 0.02$ & $14.71^{\mathrm{b}} \pm 0.32$ & $45.71^{\mathrm{b}} \pm 1.00$ & $1.61^{\mathrm{ab}} \pm 0.03$ & n.d. \\
\hline
\end{tabular}

*Mean \pm standard deviation; different lower case letters in the same column correspond to the statistical difference at the $5 \%$ level by the Tukey test. n.d. - not determined. All tests were performed with biomass at a concentration of $210 \mathrm{~g} \mathrm{~L}^{-1}$, with PU particulates from 0.355 to $0.850 \mathrm{~mm}$.

According to Table 4 (run 5), higher immobilization yield ( $\mathrm{p}<0.05)(60.29 \%)$ and enzymatic activity ( $19.40 \mathrm{U} \mathrm{g}^{-1}$ dry cell and $1.61 \mathrm{U} \mathrm{g}^{-1}$ immobilized) were observed, with the possibility of 15 reuses. And the condition for the process of in situ immobilization of Z. mobilis in flexible 
polyurethane foam, maximized with $7 \mathrm{~g}$ of biomass, $7 \mathrm{~g}$ of polyol, $3.5 \mathrm{~g}$ of isocyanate, $0.02 \mathrm{~g}$ of silicone, and used in bioconversion runs.

The bioconversion runs presented potential for production of sodium maltobionate, with the maximum concentration of $491.42 \mathrm{mmol} \mathrm{L}^{-1}$, mass productivity of $2.58 \mathrm{mmol} \mathrm{h}^{-1}$, specific productivity of $1.81 \mathrm{mmol} \mathrm{g}^{-1} \mathrm{~h}^{-1}$, and specific rate of product formation of $6.25 \mathrm{mmol}$ $\mathrm{g}^{-1} \mathrm{~h}^{-1}$ and factor of conversion of substrate into the product ( $\mathrm{Y}_{\mathrm{P} / \mathrm{So}}$ ) of 0.88 , in approximately $48 \mathrm{~h}$ of process. This potential can also be observed in $24 \mathrm{~h}$ of bioconversion, with sodium maltobionate value of $426.64 \mathrm{mmol} \mathrm{L}^{-1}$, mass productivity of $4.30 \mathrm{mmol} \mathrm{h}^{-1}$, specific productivity of $3.00 \mathrm{mmol} \mathrm{g}^{-1} \mathrm{~h}^{-1}$, and a specific rate of product formation of $6.61 \mathrm{mmol} \mathrm{g}^{-1} \mathrm{~h}^{-}$ ${ }^{1}$, respectively, with a conversion factor $(\mathrm{Y} / \mathrm{So})$ of 0.74 .

Figure 3 presents the profile for concentration and rate of sodium maltobionate formation during $48 \mathrm{~h}$ of bioconversion process, where fall in the rate of product formation over time is observed as substrate in the medium is reduced.

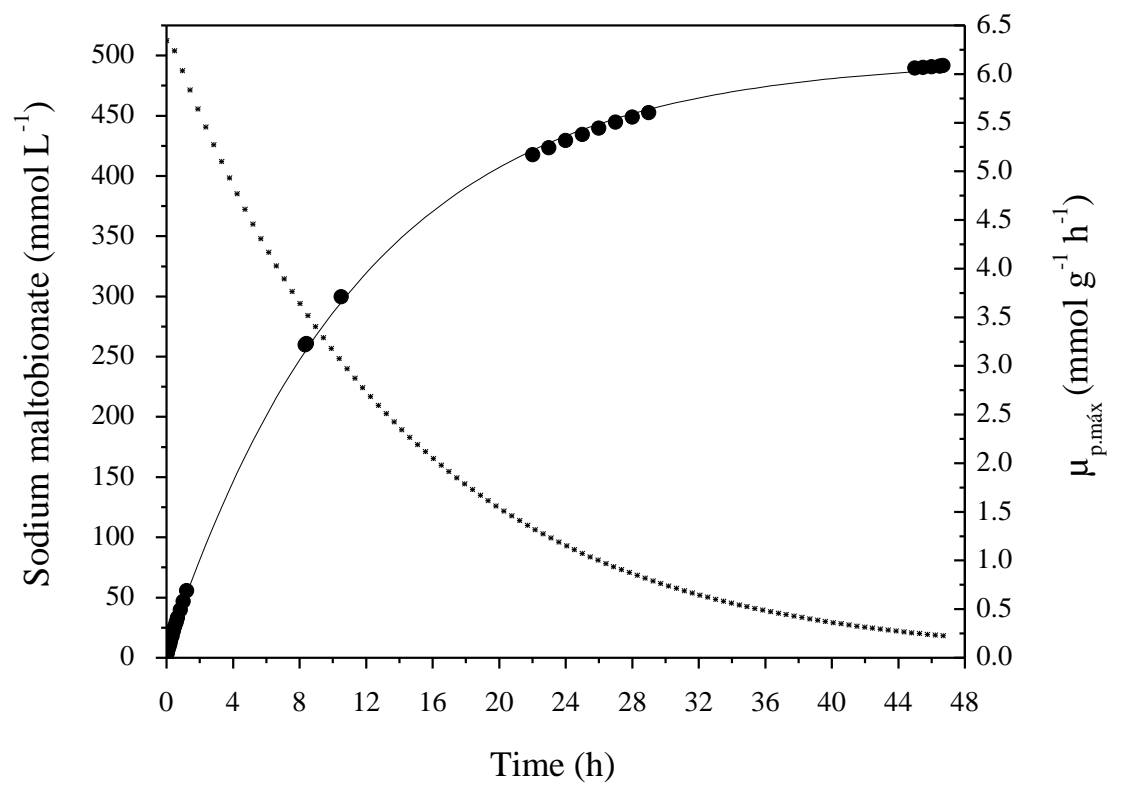

Figure 3. Concentration of sodium maltobionate produced $(\bullet)$ and specific rate of product formation $\left(\mu_{\mathrm{pmax}}\right)$ as a function of time, obtained in bioconversion runs using cells of Zymomonas mobilis immobilized in flexible polyurethane foam, from maltose and fructose $0.7 \mathrm{~mol} \mathrm{~L}^{-1}$, at $39^{\circ} \mathrm{C}$ and $\mathrm{pH} 6.4$.

The results of this study presented potentials for production of maltobionic acid salt, mainly in terms of specific productivity, when these results are compared to those of specialized literature. In $24 \mathrm{~h}$ bioconversion run, with higher biocatalyst concentration $\left(20 \mathrm{~g} \mathrm{~L}^{-}\right.$ ${ }^{1}$ ), equimolar maltose and fructose solution at $0.7 \mathrm{~mol} \mathrm{~L}^{-1}$, at $39^{\circ} \mathrm{C}$ and $\mathrm{pH} 6.4$, using Z. mobilis immobilized in calcium alginate spheres, Flores [26], Garin [38] and Malvessi [44] reported maximum concentration of maltobionic acid of 618,550 and $570 \mathrm{mmol} \mathrm{L}^{-1}$, conversion of 97 , 84 and $88 \%$ and specific productivity of $1.41,1.24$ and $0.95 \mathrm{mmol} \mathrm{g}^{-1} \mathrm{~h}^{-1}$, respectively. Flores [26] and Garin [38] also reported mass productivity of 5.67 and $2.47 \mathrm{mmol} \mathrm{h}^{-1}$ and a specific product formation rate of 4.06 and $11.16 \mathrm{mmol} \mathrm{g}^{-1} \mathrm{~h}^{-1}$, respectively. Oh et al. [9] investigated the production of maltobionic acid, however using free cells of the Pseudomonas taetrolens, at $25^{\circ} \mathrm{C}$ and with $200 \mathrm{~g} \mathrm{~L}^{-1}$ of initial maltose $\left(\sim 0.55 \mathrm{~mol} \mathrm{~L}^{-1}\right)$, and reported concentration and productivity of maltobionic acid of $200 \mathrm{~g} \mathrm{~L}^{-1}\left(\sim 558.19 \mathrm{mmol} \mathrm{L}^{-1}\right)$ and $9.52 \mathrm{~g} \mathrm{~L}^{-1} \mathrm{~h}^{-1}(\sim 26.57$ mmol L $\left.\mathrm{L}^{-1} \mathrm{~h}^{-1}\right)$, respectively. Mao et al. [7] studied the production of maltobionic acid using Pseudomonas fragi TCCC11892 free, under the conditions of $37^{\circ} \mathrm{C}, 180 \mathrm{rpm}, \mathrm{pH} 6.5$ and $24 \mathrm{~h}$ 
of maltose bioconversion (10\%), and reported maltobionic acid yield of $94.7 \mathrm{~g} \mathrm{~L}^{-1}(\sim 264.30$ mmol L $\left.{ }^{-1}\right)$ and productivity of $4 \mathrm{~g} \mathrm{~L}^{-1} \mathrm{~h}^{-1}\left(\sim 11.16 \mathrm{mmol} \mathrm{L}^{-1} \mathrm{~h}^{-1}\right)$ in the first 7 cycles.

\section{Conclusions}

The in situ immobilization of Z. mobilis in flexible polyurethane foam presented operational stability of 15 cycles with potential for application in the bioconversion of maltose into maltobionic acid, as the sodium salt. This study indicates that the in situ immobilization in PU is a promising technique, chiefly for the process simplicity, low cost, facility to separate the immobilized material from the reaction medium, and capacity to expand applications in bioconversion reactions.

\section{Funding}

This research received no external funding.

\section{Acknowledgments}

This study was financed in part by the coordination of Improvement of Higher Education Personnel - Brazil (CAPES) - Financing Code 001, National Council for Scientific and Technological Development (CNPq), Research Support Foundation of the State of Rio Grande do Sul (FAPERGS) and URI Erechim.

\section{Conflicts of Interest}

The authors declare no conflict of interest.

\section{References}

1. Green, B.A.; Yu, R.J.; Scott, E.J.V. Clinical and cosmeceutical uses of hydroxyacids. Clin. Dermatol. 2009 , 27, 495-501, https://doi.org/10.1016/j.clindermatol.2009.06.023.

2. Gutiérrez, L.P.; Hamoudi, S.; Belkacemi, K. Lactobionic acid: A high value-added lactose derivative for food and pharmaceutical applications. Internat. Dairy J. 2012, 26, 103-111, https://doi.org/10.1016/j.idairyj.2012.05.003.

3. Alonso, S.; Rendueles, M.; Díaz, M. Bio-production of lactobionic acid: Current status, applications and future prospects. Biotechnol. Adv. 2013, 31, 1275-1291, https://doi.org/10.1016/j.biotechadv.2013.04.010.

4. Cañete-Rodríguez, A.M.; Santos-Duenas, I.M.; Jiménez-Hornero, J.E.; Ehrenreich, A.; Liebl, W.; GarcíaGarcía, I. Gluconic acid: Properties, production methods and applications - An excellent opportunity for agro-industrial by-products and waste bio-valorization. Process Biochem. 2016, 51, 1891-1903, https://doi.org/10.1016/j.procbio.2016.08.028.

5. Minal, N.; Bharwade, S.B.; Chaudhary, N.N.; Jain, A.K. Lactobionic Acid: Significance and Application in Food and Pharmaceutical. Internat. J. Food Ferment. 2017, 6, 25-33, https://doi.org/10.5958/2321712X.2017.00003.5.

6. Cardoso, T.; Marques, C.; Dagostin, J.L.A.; Masson, M.L. Lactobionic acid as a potential food ingredient: recent studies and applications. J. Food Sci. 2019, 84, 1672-1681, https://doi.org/10.1111/1750-3841.14686.

7. Mao, S.; Liu, Y.; Hou, Y.; Ma, X.; Yang, J.; Han, H.; Han, J.; Jia, L.; Qin, H.; Lu, F. Efficient production of sugar-derived aldonic acids by Pseudomonas fragi TCCC11892. RSC Adv. 2018, 8, 39897-39901, https://doi.org/10.1039/C8RA07556E.

8. Suehiro, D; Okada, M; Fukami, K; Nakagawa, T.; Kayakawa, T. Maltobionic acid enhances intestinal absorption of calcium and magnesium in rats. Biosci. Biotechnol. Biochem. 2019, 83, 1766-1773, https://doi.org/10.1080/09168451.2019.1611411.

9. Oh, Y.R.; Jang, Y.A.; Hong, S.H.; Eom, G.T. High-level production of maltobionic acid from high-maltose corn syrup by genetically engineered Pseudomonas taetrolens. Biotechnol. Rep. 2020, 28, https://doi.org/10.1016/j.btre.2020.e00558.

10. Suehiro, D; Kawase, H.; Uehara, S.; Kawase, R.; Fukami, K; Nakagawa, T.; Shimada, M.; Hayakawa, T. Maltobionic acid accelerates recovery from iron deficiency-induced anemia in rats. Biosci. Biotechnol. Biochem. 2020, 84, 393-401, https://doi.org/10.1080/09168451.2019.1676694. 
11. Malvessi, E.; Carra, S.; Silveira, M.M.; Ayub, M.A.Z. Effect of substrate concentration, pH, and temperature on the activity of the complex glucose-fructose oxidoreductase/glucono- $\delta$-lactonase present in calcium alginate-immobilized Zymomonas mobilis cells. Biochem. Eng. J. 2010, 51, 1-6, https://doi.org/10.1016/j.bej.2010.04.003.

12. Malvessi, E.; Carra, S.; Pasquali, F.C.; Kern, D.B.; Silveira, M.M.; Ayub, M.A.Z. Production of organic acids by periplasmic enzymes present in free and immobilized cells of Zymomonas mobilis. J. Ind. Microbiol. Biotechnol. 2013, 40, 1-10, https://doi.org/10.1007/s10295-012-1198-6.

13. Folle, A.B.; Baschera, V.M.; Carra, L.T.V.S.; Polidoro, T.A.; Malvessi, E.; Silveira, M.M. Assessment of different systems for the production of aldonic acids and sorbitol by calcium alginate-immobilized Zymomonas mobilis cells. Bioprocess Biosyst. Eng. 2018, 41, 185-194, https://doi.org/10.1007/s00449-0171856-1.

14. Carra, S.; Rodrigues, D.C.; Beraldo, N.M.C.; Folle, A.B.; Delagustini, M.G.; Souza, B.C.; Reginatto, C.; Polidoro, T.A.; Silveira, M.M.; Bassani, V.L.; Malvessi, E. High lactobionic acid production by immobilized Zymomonas mobilis cells: a great step for large-scale process. Bioprocess Biosyst. Eng. 2020, 43, 12651276, https://doi.org/10.1007/s00449-020-02323-7.

15. Bresolin, D.; Estrella, A.S.; Valério, A.; Sayer, C.; Araújo, P.H.H.; Oliveira, D. Synthesis of a green polyurethane foam from a biopolyol obtained by enzymatic glycerolysis and its use for immobilization of lipase NS-40116. Bioprocess Biosyst. Eng. 2019, 42, 213-222, https://doi.org/10.1007/s00449-018-2026-9.

16. Cipolatti, E.P.; Valério, A.; Henriques, R.O.; Pinto, M.C.C.; Lorente, G.F.; Manoel, E.A.; Guisán, J.M.; Ninow, J.L.; Oliveira, D.; Pessela, B.C. Production of new nanobiocatalysts via immobilization of lipase B from $C$. antarctica on polyurethane nanosupports for application on food and pharmaceutical industries. Int. J. Biol. Macromol. 2020, 165, 2957-2963, https://doi.org/10.1016/j.ijbiomac.2020.10.179.

17. Hakkoymaz, O.; Mazi, H. An immobilized invertase enzyme for the selective determination of sucrose in fruit juices. Anal. Biochem. 2020, 611, https://doi.org/10.1016/j.ab.2020.114000.

18. Frota, E.G.; Sartor, K.B.; Biduski, B.; Margarites, A.C.F.; Colla, L.M.; Piccin, J.S. Co-immobilization of amylases in porous crosslinked gelatin matrices by different reticulations approaches. Int. J. Biol. Macromol. 2020, 165, 1002-1009, https://doi.org/10.1016/j.ijbiomac.2020.09.220.

19. Marco, M.; Souza, R.C.; Silva, L.M.; Bastos, G.; Dallago, R.M.; Valduga, E.; Backes, G.T.; Cansian, R.L.; Zeni, J. Pectinase production kinetics by Penicillium brasilianum immobilized in situ and by contact in polyurethane foam. Ind. Biotechnol. 2020, 14, 241-246.

20. Quayson, E.; Amoah, j.; Hama, S.; Kondo, A.; Ogino, C. Immobilized lipases for biodiesel production: Current and future greening opportunities Author links open overlay. Renew. Sustain. Energy Rev. 2020, 134, https://doi.org/10.1016/j.rser.2020.110355.

21. Yassin, M.A.; Gad, A.A.M. Immobilized Enzyme on Modified Polystyrene Foam Waste: a Biocatalyst for Wastewater Decolorization. J. Environ. Chem. Eng. 2020, 8, https://doi.org/10.1016/j.jece.2020.104435.

22. García-Bofill, M.; Sutton, P.W.; Straatman, H.; Brummund, J.; Schürmann, M.; Guillén, M.; Alvaro, G. Biocatalytic synthesis of vanillin by an immobilised eugenol oxidase: High biocatalyst yield by enzyme recycling. Appl. Catal. A, Gen. 2021, 610, https://doi.org/10.1016/j.apcata.2020.117934.

23. Wang, D.; Zheng, P.; Chen, P.; Wu, D. Immobilization of alpha-L-rhamnosidase on a magnetic metalorganic framework to effectively improve its reusability in the hydrolysis of rutin. Bior. Technol. 2021, 323, https://doi.org/10.1016/j.biortech.2020.124611.

24. Chun, U.H.; Rogers, P.L. The Simultaneous Production of Sorbitol from Fructose and Gluconic Acid from Glucose Using an Oxidoreductase of Zymomonas mobilis. Appl. Microbiol. Biotechnol. 1988, 29, 19-24, https://doi.org/10.1007/BF00258345.

25. Delagustin, M.G.; Gonçalves, E.; Carra, S.; Barcellos, T.; Bassani, V.L.; Silveira, M.M.; Malvessi, E. Sodium, potassium, calcium lactobionates, and lactobionic acid from Zymomonas mobilis: a novel approach about stability and stress tests. J. Pharm. Biomed. Anal. 2019, 174, 104-114, https://doi.org/10.1016/j.jpba.2019.05.060.

26. Flores, M.L. Síntese biocatalítica, recuperação e caracterização físico-química do ácido maltobiônico. Dissertation (Master in Biotechnology), Universidade de Caxias do Sul, Caxias do Sul, 2019.

27. Yang, J.; Xu, P.; Long, L.; Ding, S. Production of lactobionic acid using an immobilized cellobiose dehydrogenase/laccase system on magnetic chitosan spheres. Process Biochem. 2021, 100, 1-9, https://doi.org/10.1016/j.procbio.2020.09.024.

28. Rehr, B.; Wilhem, C.; Sahm, N. Production of sorbitol and gluconic acid by permeabilized cells of Zymomonas mobilis. Appl. Microbiol. Biotechnol. 1991, 35, 144-148, https://doi.org/10.1007/BF00184677.

29. Jang, I.H.; Jung, S.G.; Chang, H.S.; Chun, U.H. Improvement of the Process for Sorbitol Production with Zymomonas mobilis Immobilised in k-Carrageenan. Process Biochem. 1996, 31, 485-492, https://doi.org/10.1016/0032-9592(95)00092-5.

30. Mukhopadhyay, R.; Chatterjee, S.; Chatterjee, B.P.; Banerjeeb, P.C.; Guha, A.K. Production of gluconic acid from whey by free and immobilized Aspergillus niger. Internat. Dairy J. 2005, 15, 299-303, https://doi.org/10.1016/j.idairyj.2004.07.010. 
31. Ferraz, H.C.; Borges, C.P.; Alves, T.L.M. Sorbitol and gluconic acid production using permeabilized Zymomonas mobilis cells confined by hollow-fiber membranes. Appl. Biochem. Biotechnol. 2000, 89, 4353, https://doi.org/10.1385/ABAB:89:1:43.

32. Nyari, N.L.D.; Fernandes, I.A.; Bustamante-Vargas, C.E.; Steffens, C.; Oliveira, D.; Zeni, J.; Rigo, E.; Dallago, R.M. In situ immobilization of Candida antarctica B lipase in polyurethane foam support. J. Mol. Catal. B-Enzym. 2016, 124, 52-61, http://dx.doi.org/10.1016/j.molcatb.2015.12.003.

33. Mesquita, R.A.; Hassemer, G.; Marchiori, V.; Kiedis, J.; Valduga, E.; Junges, A. Malvessi, E.; Cansian, R.L.; Zeni, J. Synthesis of Xanthan Gum from Xanthomonas campestris Immobilized in Polyurethane. Ind. Biotechnol. 2018, 14, 276-281, https://doi.org/10.1089/ind.2018.0020.

34. Facin, B.R.; Valério, A.; Oliveira, D.; Oliveira, J.V. Developing an immobilized low-cost biocatalyst for FAME synthesis. Biocatal. Agric. Biotechnol. 2020, 29, https://doi.org/10.1016/j.bcab.2020.101752.

35. Ory, I.;Cabrera, G.; Ramirez, M.; Blandino, A. Immobilization of Cells on Polyurethane Foam. In: Immobilization of Enzymes and Cells. Methods in Molecular Biology. Rocha-Martín, J.; López-Gallego, F.; Bolivar, J.M.; Guisan, J.M. Eds.; Humana Press: New York, United States, Volume 4, 2020; pp. 407415, https://doi.org/10.1007/978-1-0716-0215-7_27.

36. Malvessi, E.; Concatto, K.; Carra, S.; Silveira, M.M. Formulation of medium for growth and production of ethanol and intracellular enzymes by Zymomonas mobilis. Braz. Arch. Biol. Technol. 2006, 49, 39-144.

37. Zachariou, M.; Scopes, R.K. Glucose-fructose oxidoreductase, a new enzyme isolated from Zymomonas mobilis that is responsible for sorbitol production. J. Bacteriol. 1986, 3, 863-869, https://doi.org/10.1128/jb.167.3.863-869.1986.

38. Garin, D.L. Uso do Sistema Enzimático de Zymomonas mobilis para a Produção de Ácidos Maltobiônico e Lactobiônico. Dissertation (Master in Biotechnology), Universidade de Caxias do Sul, Caxias do Sul, 2016.

39. Pedruzzi, I.; Silva, E.A.B.; Rodrigues, A.E. Production of lactobionic acid and sorbitol from lactose/fructose substrate using GFOR/GL enzymes from Zymomonas mobilis cells: A kinetic study. Enzyme Microb. Technol. 2011, 49, 183-191, https://doi.org/10.1016/j.enzmictec.2011.04.017.

40. Alonso, S.; Rendueles, M.; Díaz, M. A novel approach to monitor stress-induced physiological responses in immobilized microorganisms. Appl. Microbiol. Biotechnol. 2015, 99, 3573-3583, https://doi.org/10.1007/s00253-015-6517-1.

41. Moon, H.; Kim, S.; Jo, B.H.; Cha, H.J. Immobilization of genetically engineered whole-cell biocatalysts with periplasmic carbonic anhydrase in polyurethane foam for enzymatic $\mathrm{CO} 2$ capture and utilization. $J$. $\mathrm{CO}_{2}$ Util. 2020, 39, https://doi.org/10.1016/j.jcou.2020.101172.

42. Karim, A.; Bibi, Z.; Rehman, H.U.; Aman, A.; Qader, S.A.U.; Muhammad, M.H. Single step immobilization of CMCase within agarose gel matrix: kinetics and thermodynamic studies. Colloids Surf. B: Biointerfaces 2021, 200, https://doi.org/10.1016/j.colsurfb.2021.111583.

43. Vilar, W.D. Química e Tecnologia dos Poliuretanos. 2rd ed.; Vilar Consultoria: Rio de Janeiro, Brazil, 1999.

44. Malvessi, E. Produção de Sorbitol e Ácidos Orgânicos por Zymomonas mobilis. Thesis (Doctorate in Science), Universidade Federal do Rio Grande do Sul, Porto Alegre, 2008. 